\title{
Identification of areas vulnerable to soil erosion risk in India using GIS methods
}

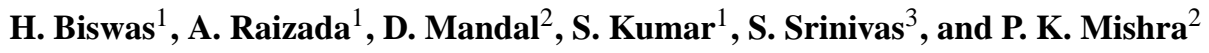 \\ ${ }^{1}$ ICAR-Indian Institute of Soil and Water Conservation, Research Centre, Hospet Road, Cantonment, \\ Bellary, Karnataka, India \\ ${ }^{2}$ ICAR-Indian Institute of Soil and Water Conservation, 218, Kaulagarh Road, Dehradun 248 195, Uttarakhand, India \\ ${ }^{3}$ National Bureau of Soil Survey and Land Use Planning, Regional Centre, Hebbal, Karnataka, India \\ Correspondence to: H. Biswas (hritbis@yahoo.co.in)
}

Received: 27 April 2015 - Published in Solid Earth Discuss.: 4 June 2015

Revised: 12 September 2015 - Accepted: 30 October 2015 - Published: 30 November 2015

\begin{abstract}
This paper attempts to provide information for policymakers and soil conservation planners in the form of district-wise soil erosion risk (SER) maps prepared for the state of Telangana, India. The SER values for each district were computed by extracting the information on grid-wise soil erosion and soil loss tolerance limit values existing on the country-scale in a GIS environment. The objectives of the study were to (i) identify the areas of the state with a high erosion risk, and (ii) identify areas with an urgent need of conservation measures. The results reveal that around $69 \%$ of the state has a negligible risk of soil erosion above the tolerance limits, and does not call for immediate soil conservation measures. The remaining area $(2.17 \mathrm{M} \mathrm{ha})$ requires conservation planning. Four districts, viz. Adilabad, Warangal, Khammam, and Karimnagar are the most risk-prone with more than one-quarter of their total geographical areas showing net positive SER values. In order to obtain a clearer picture and categorize the districts based on their extent of vulnerability, weighted erosion risk values were computed. Adilabad, Warangal, and Khammam were identified as the worst-affected districts in terms of soil erosion, and therefore are in need of immediate attention of natural resource conservation.
\end{abstract}

\section{Introduction}

Soil is a finite and non-renewable natural resource. It takes between 200 and 1000 years for $2.5 \mathrm{~cm}$ of topsoil to form under cropland conditions (Pimentel et al., 1995). Fertile soils have always been the mainstay of prosperous civilizations, and great civilizations have fallen in the past because they failed to prevent the degradation of soils on which they survived (Diamond, 2005). The inherent productivity of many lands has been dramatically reduced as a result of soil erosion, accumulation of salinity, and nutrient depletion (Scholes and Scholes, 2013).

Global estimates show an increasing trend in degraded areas, with other areas becoming vulnerable to various forms of degradation (Reich et al., 2001; FAO, 2011; UNCCD, 2013). Similarly, in India, areas under land degradation have been on the rise, particularly during the last few decades, and the latest estimates show that an area of about $120.72 \mathrm{M}$ ha (million hectares) is affected by various forms of land degradation, of which $82.57 \mathrm{M}$ ha is solely accounted for by waterinduced soil erosion in excess of $10 \mathrm{Mg} \mathrm{ha}^{-1} \mathrm{yr}^{-1}$ (Maji, 2007).

Among the Indian states, erstwhile Andhra Pradesh (AP) was the third most vulnerable in terms of soil erosion, with nearly $40 \%$ (10.93 M ha) of the total geographical area (TGA) being eroded by water (Maji et al., 2010). Reddy et al. (2005) reported that the 10 districts of the newly formed Telangana, which was a part of erstwhile AP, accounted for $42 \%$ of the water-erosion-affected area (soil loss $>5 \mathrm{Mg} \mathrm{ha}^{-1} \mathrm{yr}^{-1}$ ) of the undivided state. On computing the extent of soil erosion in Telangana alone from the report by Reddy et al. (2005), it was found that more than two-thirds of the TGA of the state is affected by soil erosion.

The above situation may look alarming for the soil conservation planners of the state, but the statistics only provide 


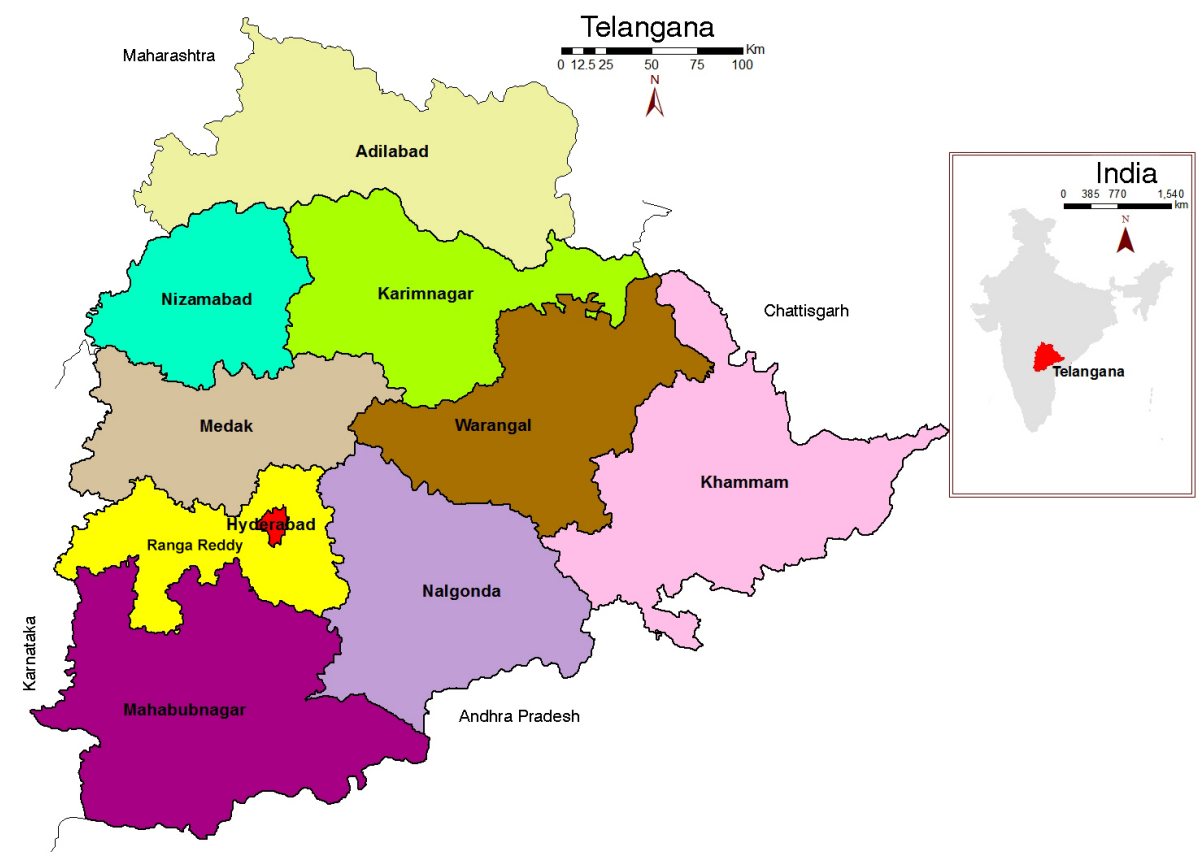

Figure 1. Outline of the study area.

information on the amount of soil lost under the present set of conditions, without taking into account the inherent resilient capacity of the soil to resist erosive forces. This capacity has been quantified through the adjusted soil loss tolerance limits (SLTL), or adjusted $T$ values (Mandal et al., 2006), which are dynamic, discrete and site-specific values estimated with the help of easily recorded minimum data sets. This approach led to the mapping of adjusted $T$ values for different agroecological regions and physiographic zones of India (Bhattacharyya et al., 2008; Lakaria et al., 2008; Jha et al., 2009; Lakaria et al., 2010).

Assessment of soil erosion vulnerability or risk on regional and national scales by combining empirical models like the Universal Soil Loss Equation (USLE) and the Revised Universal Soil Loss Equation (RUSLE) with remote sensing and geographic information systems (GIS) has been done by several researchers (Lee, 2004; Fu et al., 2005; Sotiropoulou et al., 2011). Similarly, in India GIS-aided soil erosion mapping has been done on watershed (Prasannakumar et al., 2012; Chatterjee et al., 2014) and regional (Reddy et al., 2005; Ramamurthy et al., 2014) scales. Soil erosion risk or vulnerability in most of the earlier studies did not consider the SLTL values.

The erosion and SLTL maps of any region or state can be combined together using a GIS platform to generate the soil erosion risk (SER) map by following a simple protocol (Mandal and Sharda, 2013). Such a map is expected to be the most simplified one for the purpose of conservation planning. Some studies have been carried out on the systematic and scale-specific assessment of soil erosion risks (Deumlich et al., 2006; Volk et al., 2010; Sharda et al., 2013) to serve as tools for decision-making by policymakers. Most development plans in India are usually made for and implemented at district level as the functional unit. Therefore, in order to achieve cooperation with the functionaries of each state, we need to provide them with district-wise information which will aid in prioritizing soil conservation activities. This paper attempts to provide, for the first time in the country, such information in the form of district-wise SLTL and SER maps prepared in a GIS environment for the state of Telangana. The objectives of this paper are to (i) identify the areas of the state with a high erosion risk, and (ii) identify areas with an urgent need of conservation measures.

\section{Materials and methods}

\subsection{Study area}

Andhra Pradesh has recently (2 June 2014) been bifurcated into two states, viz. Andhra Pradesh and Telangana, comprising 13 and 10 districts, respectively. The study was conducted on Telangana (Fig. 1), the twenty-ninth and the twelfth-largest state of India, comprising 10 districts, and with a total geographical area (TGA) of $11.48 \mathrm{M}$ ha. Telangana is situated on the Deccan Plateau, in the central stretch of the eastern seaboard of the Indian peninsula. The state is situated between $15^{\circ} 50^{\prime}$ and $19^{\circ} 45^{\prime} \mathrm{N}$ and between $77^{\circ} 25^{\prime}$ and $81^{\circ} 45^{\prime} \mathrm{E}$. It is bordered by the states of Odisha and Chhattisgarh in the north, by Maharashtra and Karnataka in the west, and by Andhra Pradesh in the east and south. The 


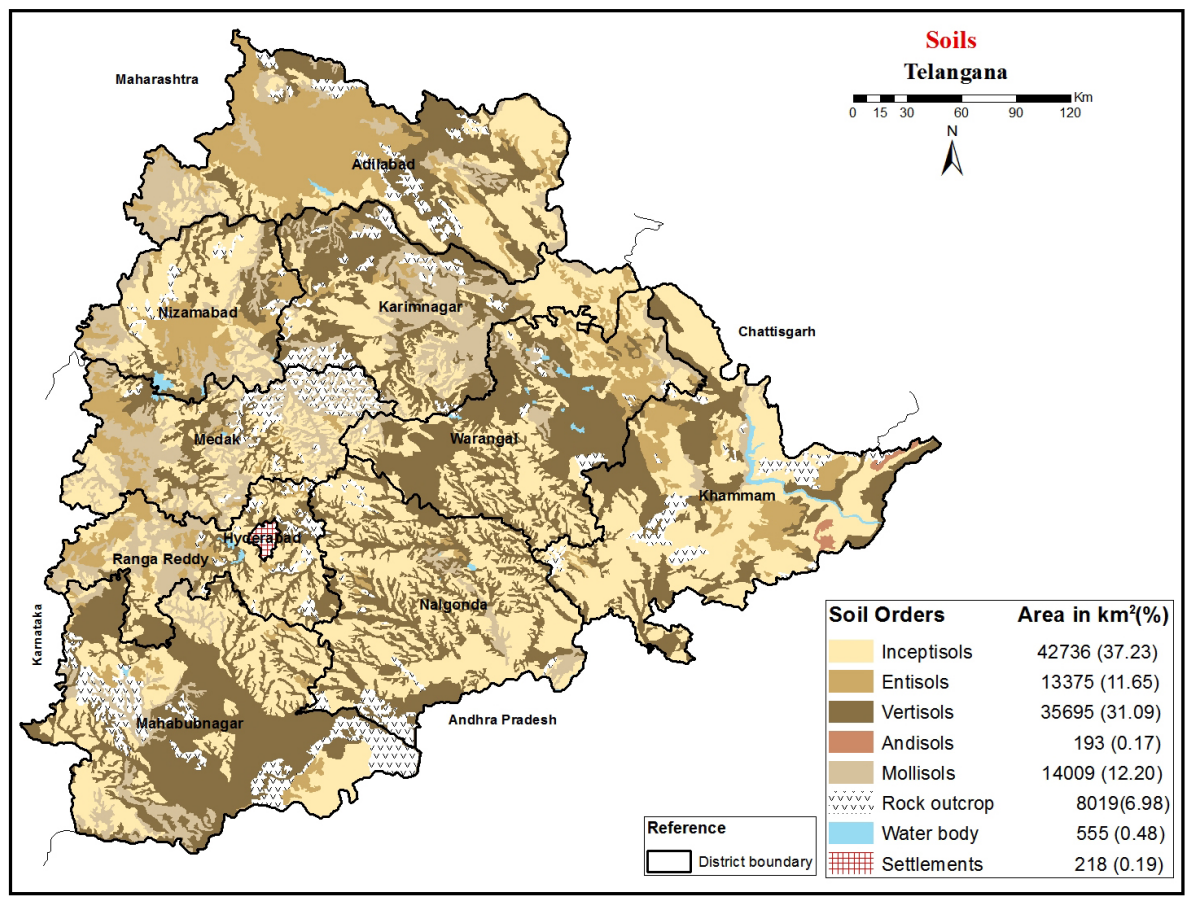

Figure 2. Major soil orders of Telangana.

state is drained by two major rivers, viz. Godavari and $\mathrm{Kr}$ ishna, and by minor rivers such as the Bhima, the Manjira, and the Musi.

The study area is covered by igneous (pink and gray granites and basalt) and metamorphic (granite gneiss) depositions (Satyavathi and Reddy, 2004). The major soil orders (Fig. 2) occurring in these landforms are Inceptisols, Vertisols, Entisols, Alfisols, and Mollisols (Reddy et al., 1996).

Telangana is a semiarid area and has a predominantly hot and dry climate. It has been categorized into agro-climatic region 10 (southern plateau and hills), agro-ecological region (AER) 7 (Deccan Plateau (Telangana), and Eastern Ghats, a hot semiarid ecoregion), and agro-ecological subregion 7.2 (north Telangana Plateau, a hot, moist, semiarid area, with deep loamy and clayey mixed red and black soils, a medium to very high available water capacity, and a growing period of 120-150 days) (Gajbhiye and Mandal, 2005). On the basis of agro-climatic zonation, Telangana can be broadly divided into the northern Telangana zone (NTZ) and the southern Telangana zone (STZ). While the NTZ receives 810 $1135 \mathrm{~mm}$ rainfall which is climatically categorized as being semiarid, moist tropical, STZ receives $560-970 \mathrm{~mm}$ rainfall and is classified as semiarid, dry tropical (Satyavathi and Reddy, 2004).

According to statistical data of Andhra Pradesh (Government of AP, 2012), the state has a combined forest cover of about $2.74 \mathrm{Mha}$, which is about $45 \%$ of the forest area of erstwhile Andhra Pradesh. The net sown area of the state is $40 \%$ of the TGA, with a cropping intensity of $124 \%$. The net irrigated area (NIA) of the state is $1.88 \mathrm{M}$ ha, which is $44.5 \%$ of the net cropped area and only $39 \%$ of undivided Andhra Pradesh. Most of the irrigation is provided by wells, with the area that is irrigated being nearly $72 \%$ of the NIA.

\subsection{Soil loss tolerance limits (SLTL) map}

The methodology followed for the development of SLTL values has been described before (Mandal et al., 2006; Lakaria et al., 2008). The soil mapping units (pertaining to Telangana), selected for the development of the soil map of undivided Andhra Pradesh (Reddy et al., 1996), were used for preparation of the SLTL map. A two-way matrix presenting soil depths against soil states/groups was used as a guide in assigning the $T$ values for each soil mapping unit.

\subsubsection{Selection of indicators and assigning weights}

The soil state/group for each mapping unit was obtained by employing a weighted additive model, wherein five indicators selected from the sensitivity analysis of the Water Erosion Productivity Project (Nearing et al., 1990) were assigned scores and weighted as per their relative importance. The five selected indicators were (i) infiltration rate, which was assigned the highest weight of 0.35 , since the primary function of the soil with respect to erodibility is to permit infiltration (Karlen and Stott, 1994); (ii) bulk density, which was given a weight of 0.10 , as it complements the primary function (i.e. infiltration); (iii) soil erodibility factor, $K$, which indicates resistance to physical degradation, and was assigned a weight 
Table 1. Range of soil properties and their scaling (0-1).

\begin{tabular}{|c|c|c|c|c|c|c|c|}
\hline \multirow[t]{2}{*}{ Soil attribute } & & \multicolumn{5}{|c|}{ Ranking/category } & \multirow{2}{*}{$\begin{array}{r}\text { Crossover } \\
\text { point }\end{array}$} \\
\hline & & 1 & 2 & 3 & 4 & 5 & \\
\hline \multirow[t]{2}{*}{ Infiltration $\left(\mathrm{cm} \mathrm{h}^{-1}\right)$} & Range & $0.5-1.0$ & $1.0-2.0$ & $2.0-3.5$ & $3.5-5.0$ & $>5.0$ & 2.0 \\
\hline & Score & 0.2 & 0.3 & 0.5 & 0.8 & 1 & \\
\hline \multirow[t]{2}{*}{ Bulk density $\left(\mathrm{Mg} \mathrm{m}^{-3}\right)$} & Range & $<1.40$ & $1.40-1.47$ & $1.48-1.55$ & $1.56-1.63$ & $>1.63$ & 1.47 \\
\hline & Score & 1 & 0.8 & 0.5 & 0.3 & 0.2 & \\
\hline \multirow[t]{2}{*}{ Erodibility factor $(K)$} & Range & $<0.10$ & $0.10-0.29$ & $0.30-0.49$ & $0.50-0.69$ & $>0.70$ & 0.30 \\
\hline & Score & 1 & 0.8 & 0.5 & 0.3 & 0.2 & \\
\hline \multirow[t]{2}{*}{ Total organic carbon $(\%)$} & Range & $<0.50$ & $0.50-0.75$ & $0.75-1.00$ & $1.00-1.50$ & $>1.50$ & 0.75 \\
\hline & Score & 0.2 & 0.3 & 0.5 & 0.8 & 1 & \\
\hline \multirow[t]{2}{*}{$\mathrm{pH}$} & Range & $<5.0 ;>9.0$ & $5.0-5.5 ; 8.5-9.0$ & $5.5-6.0 ; 8.0-8.5$ & $6.0-6.5 ; 7.5-8.0$ & $6.5-7.5$ & $6.0 ; 8.0$ \\
\hline & Score & 0.2 & 0.3 & 0.5 & 0.8 & 1 & \\
\hline
\end{tabular}

of 0.25 ; (iv) soil organic carbon, with a weight of 0.15 ; and (v) soil $\mathrm{pH}$, which is a general indicator of fertility and was assigned a weight of 0.15 .

Data on soil texture, organic carbon, and fertility parameters for each mapping unit were compiled from various publications of NBSSLUP (NBSSLUP, 2002; Reddy et al., 1996). Basic infiltration rate and bulk density were derived by appropriate pedotransfer function using SSWATER, and soil erodibility factor, $K$, was computed based on texture and soil organic matter content (Kirkby and Morgan, 1980).

\subsubsection{Scoring technique}

The indicator values were transformed into dimensionless scores ranging from 0 to 1 through fuzzy modelling (Wymore, 1993) using a scoring algorithm. With this approach, attribute values were converted to common membership grades (0-1), according to class limits specified by analysts based on experience or conventionally imposed definitions (McBratney and Odeh, 1997). If $\operatorname{MF}\left(x_{i}\right)$ represents individual membership function (MF) values of $x$ for the $i$ th soil property, then the basic model can be described as

$\operatorname{MF}\left(x_{i}\right)=\left[1 /\left(1+\left\{\left(x_{i}-b\right) / d\right\}^{2}\right)\right]$,

where $b$ refers to the central concept or ideal value; and $d$ refers to the width of the transition zone.

As there are various soil characteristics to be rated, the membership function values of individual soil characteristics under consideration were then combined using a convex combination function to produce a joint membership function (JMF) for all attributes, $Y$, as follows:

$\operatorname{JMF}(Y)=\sum_{i=1}^{n} \lambda_{i} \operatorname{MF}\left(x_{i}\right)$,

where $\lambda_{i}$ is the weighting factor for the $i$ th soil property $x_{i}$; and $\operatorname{MF}\left(x_{i}\right)$ is the membership function for the $i$ th soil property $x$.
Table 1 depicts the scores assigned to different ranges of indictor values that normally exist in field conditions. Three models, viz. optimum range (for soil $\mathrm{pH}$ ), "more is better" (for organic carbon and infiltration rate) and "less is better" (for bulk density and soil erodibility factor) were used for scoring the indicators. The optimum range for soil $\mathrm{pH}$ is between 6.5 and 7.5, and any value occurring in this range was given the highest score of 1 . Higher values of soil organic carbon and infiltration rates are known to improve soil moisture dynamics and reduce erosion; therefore the values in excess of $1.5 \%$ and $5 \mathrm{~cm} \mathrm{~h}^{-1}$, respectively, were associated with a score of 1 . The opposite is the case with bulk density and soil erodibility factor, $K$; and values below $1.4 \mathrm{Mg} \mathrm{m}^{-3}$ and 0.10 , respectively, were associated with the highest score of 1 . The associated score of 1 represents the highest potential function for that system, i.e. the indicator is non-limiting to particular soil functions and processes. The forms of equations for the three models are as follows:

1. optimum range:

$$
\operatorname{MF}\left(x_{i}\right)=1 \quad \text { if } \quad\left(b_{1}+d_{1}\right)<x_{i}<\left(b_{2}-d_{2}\right)
$$

2. asymmetrical left ("more is better"):

$$
\begin{aligned}
\operatorname{MF}\left(x_{i}\right)= & {\left[1 /\left(1+\left\{\left(x_{i}-b_{1}-d_{1}\right) / d_{1}\right\}^{2}\right)\right] } \\
& \text { if } \quad x_{i}<\left(b_{1}+d_{1}\right)
\end{aligned}
$$

3. asymmetrical right ("less is better"):

$$
\begin{aligned}
\operatorname{MF}\left(x_{i}\right)= & {\left[1 /\left(1+\left\{\left(x_{i}-b_{2+} d_{2}\right) / d_{2}\right\}^{2}\right)\right] } \\
& \text { if } \quad x_{i}>\left(b_{2}-d_{2}\right) .
\end{aligned}
$$

The model parameters include the lower crossover point, the central concept $(b)$, the upper crossover point, and the width of the transition zone $(d)$. The lower and upper crossover points represent the situation where a land attribute 
Table 2. Assignment of $T$ value to soil mapping units based on soil depth and aggregated score.

\begin{tabular}{lccc}
\hline Soil depth $(\mathrm{cm})$ & Group I $(Q<0.33)^{*}$ & Group II $(Q=0.33-0.66)$ & Group III $(Q>0.66)$ \\
\cline { 2 - 4 } & \multicolumn{3}{c}{ Annual permissible soil loss limit $\left(\mathrm{Mg} \mathrm{ha}^{-1}\right)$} \\
\hline$<25$ & 2.5 & 2.5 & 7.5 \\
$25-50$ & 2.5 & 5.0 & 7.5 \\
$50-100$ & 5.0 & 7.5 & 10.0 \\
$100-150$ & 7.5 & 10.0 & 10.0 \\
$>150$ & 10.0 & 12.5 & 12.5 \\
\hline
\end{tabular}

${ }^{*} Q$ is soil state (the total aggregated score); source: Lakaria et al. (2008).

is at a marginal level for a given purpose, while $b$ is for an ideal level (Burrough et al., 1992; Sys, 1985). For example, for infiltration an ideal value was set at $5 \mathrm{~cm} \mathrm{~h}^{-1}$ following the critical level concept developed by Lal (1996), while the crossover point (marginal) was set at $2 \mathrm{~cm} \mathrm{~h}^{-1}$. Similarly, the crossover points in the cases of organic carbon, bulk density, and erodibility factor, $K$, were set at $0.75 \%$, $1.47 \mathrm{Mg} \mathrm{m}^{-3}$, and 0.30 , respectively, based on expert judgement and previous experience in Indian conditions. Soil $\mathrm{pH}$ has two crossover points at 6.0 and 8.0, as it is felt that any deviation below and above these two values, respectively, has a negative impact on soil fertility and therefore, on soil erosion.

It was assumed that the general relationships between a given indicator and the soil functions were relatively constant. The relationship is expressed in the shape of an indicator's scoring curve (Karlen and Stott, 1994; Andrews et al., 2002). Thus use was made of an increasing logistic curve, "more is better", as for infiltration, organic carbon, and fertility; and a lower asymptotic curve, "less is better", as for bulk density (Grossman et al., 2001). A "less is better" function was also used for soil erodibility (Harris et al., 1996).

\subsubsection{Integration}

Ratings obtained for different soil functions when converted to a $0-1$ scale were multiplied by their respective weights. The aggregate of all the weighted parameters was then used to quantify the state of soil $(Q)$ for each soil mapping unit:

$Q=q_{\mathrm{we}} w_{\mathrm{we}}+q_{\mathrm{wt}} w_{\mathrm{wt}}+q_{\mathrm{rpd}} w_{\mathrm{rpd}}+q_{\mathrm{rbd}} w_{\mathrm{rbd}}+q_{\mathrm{spg}} w_{\mathrm{spg}}$,

where $q$ is the individual rating for different soil functions, such as $q_{\mathrm{we}}$ represented by the infiltration rate; $q_{\mathrm{wt}}$ the water transportation; $q_{\mathrm{rpd}}$ the rate of physical degradation; $q_{\mathrm{rbd}}$ the rate of biological degradation; $q_{\mathrm{spg}}$ the ability of soil to sustain plant growth; and $w$ is the weight assigned to each function.

\subsubsection{Soil grouping}

Soils were classified into three groups: I $(Q<0.33)$, II ( $Q=0.33-0.66)$, or III $(Q>0.66)$, based on the aggregated score $(Q)$ as obtained in Eq. (6). Therefore, soils in group III perform all functions at optimal levels and thus may erode at higher rates than those in groups I or II. A general guide developed at the Iowa State University Statistical Laboratory (USDA-NRCS, 1999) was used to arrive at the erosion tolerance $(T)$ limits (Table 2), based on the soil group of the unit and soil depth.

The $T$ values were computed for each $10 \mathrm{~km} \times 10 \mathrm{~km}$ grid point earmarked by NBSSLUP for the preparation of maps related to soil (Reddy et al., 1996) and potential soil erosion rates (Reddy et al., 2005) of undivided Andhra Pradesh. The values of $T$ and potential soil erosion rates (PSER) pertaining to the grid points located in the 10 districts of Telangana were extracted from those earlier maps and new SLTL and PSER maps were carved out for the state on an ArcGIS (version 9.3) platform.

\subsection{Soil erosion risk (SER) map}

The spatial layers of SLTL and PSER maps were integrated using the ArcGIS (version 9.3) software at $10 \mathrm{~km} \times 10 \mathrm{~km}$ grid levels to generate the SER statistics and the map of the Telangana state. The intersection of SLTL and PSER provides information on the actual risk associated with soil erosion. More specifically, the SER was computed for each point as follows:

$\mathrm{SER}=$ median value of the PSER $-T$ value

The potential rates of erosion (Reddy et al., 2005) were classified into various ranges, viz., $<5,5-10,10-15$, 15-20, 20-40, and $>40 \mathrm{Mg} \mathrm{ha}^{-1} \mathrm{yr}^{-1}$, representing slight, moderate, strong, severe, very severe, and extremely severe erosion. For our purposes, we first reduced the number of classes to four: (a) $<5 \mathrm{Mgha}^{-1} \mathrm{yr}^{-1}$, with a midvalue of $2.5 \mathrm{Mg} \mathrm{ha}^{-1} \mathrm{yr}^{-1}$, (b) $5-10 \mathrm{Mgha}^{-1} \mathrm{yr}^{-1}$, with a mid-value of $7.5 \mathrm{Mg} \mathrm{ha}^{-1} \mathrm{yr}^{-1}$, (c) $10-20 \mathrm{Mg} \mathrm{ha}^{-1} \mathrm{yr}^{-1}$, with a mid-value of $15.0 \mathrm{Mg} \mathrm{ha}^{-1} \mathrm{yr}^{-1}$, and (e) 20 $40 \mathrm{Mgha}^{-1} \mathrm{yr}^{-1}$, with a mid-value of $30 \mathrm{Mgha}^{-1} \mathrm{yr}^{-1}$. The class $>40 \mathrm{Mgha}^{-1} \mathrm{yr}^{-1}$ was combined with the 20 $30 \mathrm{Mg} \mathrm{ha}^{-1} \mathrm{yr}^{-1}$ class because the area under the former class was the lowest $(12 \%)$ in the state. As the potential 
Table 3. Potential rates of soil erosion in different districts of Telangana.

\begin{tabular}{|c|c|c|c|c|c|c|c|}
\hline \multirow[t]{2}{*}{ District } & \multirow[t]{2}{*}{$\begin{array}{l}\text { Geographical } \\
\text { area }\left(\mathrm{km}^{2}\right)\end{array}$} & \multicolumn{3}{|c|}{$\begin{array}{c}\text { Area }\left(\mathrm{km}^{2}\right) \text { affected by } \\
\text { erosion rates }\left(\mathrm{Mg} \mathrm{ha}^{-1} \mathrm{yr}^{-1}\right)\end{array}$} & \multicolumn{3}{|c|}{$\begin{array}{c}\% \text { of district area affected by } \\
\text { a particular erosion rate }\end{array}$} \\
\hline & & $<5$ & $5-10$ & $>10$ & $<5$ & $5-10$ & $>10$ \\
\hline Adilabad & 16142.12 & $2959.21(7.5)$ & $6625.15(15.5)$ & $5612.89(23.6)$ & 18.3 & 41.0 & 34.8 \\
\hline Karimnagar & 11742.98 & 4997.05 (12.6) & $2986.33(7.0)$ & $2870.42(12.0)$ & 42.6 & 25.4 & 24.4 \\
\hline Khammam & 16666.34 & $4038.90(10.2)$ & $7698.89(18.1)$ & $3613.25(15.2)$ & 24.2 & 46.6 & 21.7 \\
\hline Mahabubnagar & 18414.02 & $8587.28(21.7)$ & $4347.08(10.2)$ & $3308.10(13.9)$ & 46.6 & 23.6 & 18.0 \\
\hline Medak & 9698.98 & $3492.79(8.8)$ & $4342.22(10.2)$ & $658.02(2.8)$ & 36.0 & 44.8 & 6.8 \\
\hline Nalgonda & 13914.23 & $5320.45(13.4)$ & $5460.86(12.8)$ & $2463.20(10.3)$ & 38.2 & 39.3 & 17.7 \\
\hline Nizamabad & 7887.30 & $2590.29(6.6)$ & $3180.27(7.5)$ & $1661.18(7.0)$ & 32.8 & 40.3 & 21.1 \\
\hline Ranga Reddy & 7373.98 & $1832.69(4.6)$ & $4145.30(9.7)$ & $818.12(3.4)$ & 24.9 & 56.2 & 11.1 \\
\hline Warangal & 12749.11 & $5733.15(14.5)$ & $3850.46(9.0)$ & $2818.76(11.8)$ & 45.0 & 30.2 & 22.1 \\
\hline Whole state & 114802.18 & 3955181 & 4263656 & 2382394 & 34.4 & 37.1 & 20.8 \\
\hline
\end{tabular}

Values in parentheses are percentages of the state area affected by that particular erosion class.

soil erosion rates were defined as class ranges with no exact value, the mid-value of each class was considered for the ease of subtraction between PSER and $T$ values corresponding to each point in the map. The SER values thus obtained for an individual grid point were placed in one of the five categories created for conservation planning and prioritization purposes: <0, 0-5, 5-10, 10-20, and 20-30 $\mathrm{Mg} \mathrm{ha}^{-1} \mathrm{yr}^{-1}$. The SER map was generated for the state as a final product for conservation planners and other development agencies.

\subsection{Weighted soil erosion risk (WSER)}

Since the extent and severity of erosion risk in each district has large variations, it is difficult to identify the most affected district in the state. To overcome this problem and prioritize the districts, a simplified weighted erosion risk (WSER) index for each district was computed, which simultaneously combines information on two parameters: (a) percentage of the geographical area of a district affected by soil erosion risk; (b) and the severity of the soil erosion risk to each district.

Since the severity of the erosion risk is expressed in a class with a pre-defined range, the median of each class range was chosen: (a) to represent the class, and (b) as a weight to signify the severity of the erosion risk in an affected area. Therefore, the weighted erosion risk is expected to assign high priority to a district with a greater proportion of its geographical area in the high erosion risk class.

$\operatorname{WSER}_{j}=\sum_{i=1}^{n} A_{j i} \cdot W_{i}$,

where $j$ is the number of district in the state, i.e. 9 , and $i(1,2, \ldots, n)$ is the number of erosion risk classes, i.e. 4 . $\mathrm{WSER}_{j}$ is the weighted soil erosion risk to the $i$ th district, $A_{j i}$ is the area in the $i$ th class in the $j$ th district, and $W_{i}$ is the weight assigned to the $i$ th class.
Further, for the ease of interpretation and classification, values of WSER were converted into the WSER index using the given formulae (Kumar et al., 2014):

WSERI $_{j}=\frac{\text { WSER }_{j}-\text { WSER }_{\text {Min }}}{\text { WSER }_{\text {Max }}-\text { WSER }_{\text {Min }}}$,

where $\mathrm{WSERI}_{j}$ refers to the weighted soil erosion risk index for the $j$ th district, WSER $_{\text {Min }}$ refers to the minimum value of WER among all the districts, and WSER Max $_{\text {refers to the }}$ maximum value of WER among all the districts.

Based on the WSER index values, districts were classified into three classes representing priority class I, II and III, using percentile analysis. A percentile is a value below which a certain proportion of the observations lie. It is a measure that tells us how much percentage of the total frequency scored (in our case, WER index scores) is at or below a certain point. We estimated two such data points using the percentile function of Microsoft Excel, viz. 33 and 66 percentile, represented by the estimated values of 0.290 and 0.607 , respectively. Therefore, all the districts based on their WER index scores were divided into three equal groups or priority classes (PCs): (i) PC-I, representing districts with an WER value less than 0.290; (ii) PC-II, for districts with an WER index value between 0.290 and 0.607 ; and (iii) PC-III, for districts with an WER index score of more than 0.607.

\section{Results and discussion}

\subsection{Potential rates of soil erosion}

The district-wise areas subjected to different classes of annual potential soil loss are shown in Table 3. A major part of the TGA of the state $(37 \%)$ has moderate rates of erosion $\left(5-10 \mathrm{Mg} \mathrm{ha}^{-1} \mathrm{yr}^{-1}\right)$, while about $20 \%$ is prone to erosion rates in excess of $10 \mathrm{tha}^{-1}$. In respect to the latter, Adilabad leads in the table, with more than one-third of its 


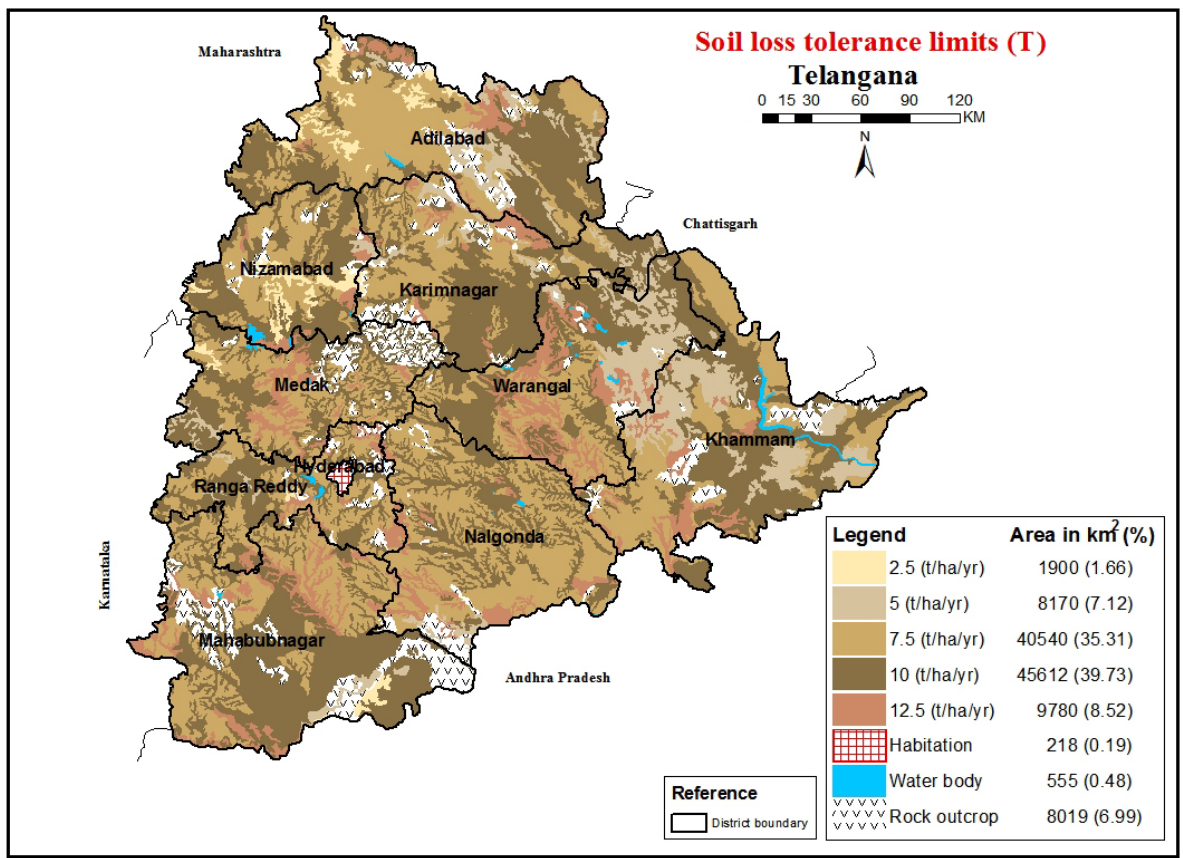

Figure 3. Soil loss tolerance map of Telangana.

area being strongly eroded. Extremely severe erosion rates (> $20 \mathrm{Mg} \mathrm{ha}^{-1} \mathrm{yr}^{-1}$ ) occur in about $0.25 \mathrm{M}$ ha of the state, with roughly $83 \%$ credited to the three districts of Warangal, Khammam, and Adilabad alone. Low soil organic matter, steep slopes, and rainfall pattern (for a prolonged period and of high intensity) are major contributing factors to the severe erosion in these areas. A comparison among the different districts of Telangana with respect to the percentage area in different erosion classes has also been made in Table 3. While Adilabad, Karimnagar, Khammam, Nizamabad, and Warangal have more than $20 \%$ of their total areas affected by $>10 \mathrm{Mg} \mathrm{ha}^{-1} \mathrm{yr}^{-1}$, the class of $5-10 \mathrm{Mg} \mathrm{ha}^{-1} \mathrm{yr}^{-1}$ needs to be focused upon. In this respect, 56, 46, and $44 \%$ of Ranga Reddy, Khammam, and Medak, respectively, may be targeted for soil and water conservation measures. This is necessary to prevent further escalation of erosion rates and to increase chances of recovery.

\subsection{Soil loss tolerance limits $(T)$}

The SLTL map of the Telangana district is shown in Fig. 3. Soils prone to high rates of erosion may not require immediate conservation measures if they have high $T$ values. However, soils with slight or moderate rates of erosion but with low $T$ values call for urgent conservation strategies (Lakaria et al., 2008). Although more than $20 \%$ of the TGA of Telangana is prone to erosion rates $>10 \mathrm{Mg} \mathrm{ha}^{-1} \mathrm{yr}^{-1}, 48 \%$ of the area of the state can tolerate soil loss up to $10 \mathrm{Mg} \mathrm{ha}^{-1} \mathrm{yr}^{-1}$. Figure 4 depicts the percent distribution of different $T$ classes across the districts of the state. Only $9 \%$ of the state has

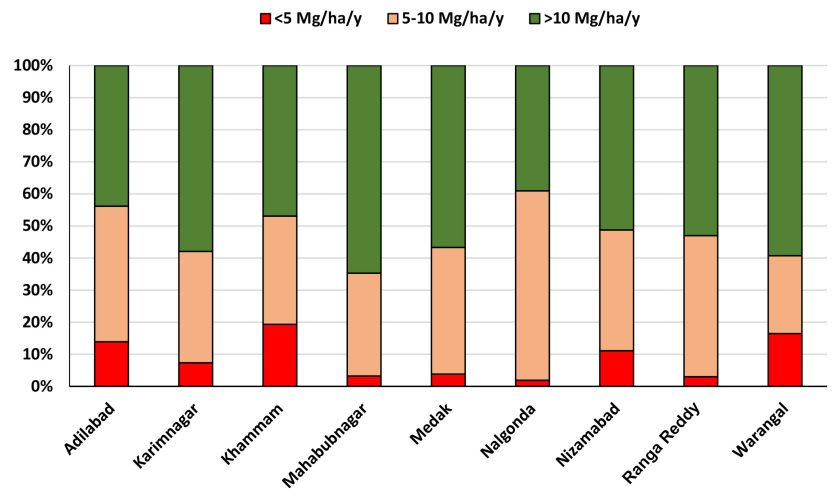

Figure 4. Percentage area distribution of different districts of Telangana under different $T$ (or soil loss tolerance limit) value classes.

$T$ values below $5 \mathrm{Mg} \mathrm{ha}^{-1} \mathrm{yr}^{-1}$. About 17.8, 16.0, 13.1, and $10.5 \%$ of the soils of Khammam, Warangal, Adilabad, and Nizamabad, respectively, can tolerate the erosion rate exceeding $5 \mathrm{Mg} \mathrm{ha}^{-1} \mathrm{yr}^{-1}$. An area of $0.19 \mathrm{M}$ ha in the state has a $T$ value of only $2.5 \mathrm{Mg} \mathrm{ha}^{-1} \mathrm{yr}^{-1}$, of which $79 \%$ occurs in the two districts of Adilabad and Nizamabad. A priority area with a target value of $2.5 \mathrm{tha}^{-1} \mathrm{yr}^{-1}$ is considered as most critical, requiring immediate attention for the adoption of appropriate conservation strategies. A similar view was expressed by Lakaria et al. (2008)

Results of various soil and water conservation programmes on a watershed basis in different agro-climatic regions of the country revealed an increase in productivity by bringing the soil loss near or below the tolerance limit (Singh, 


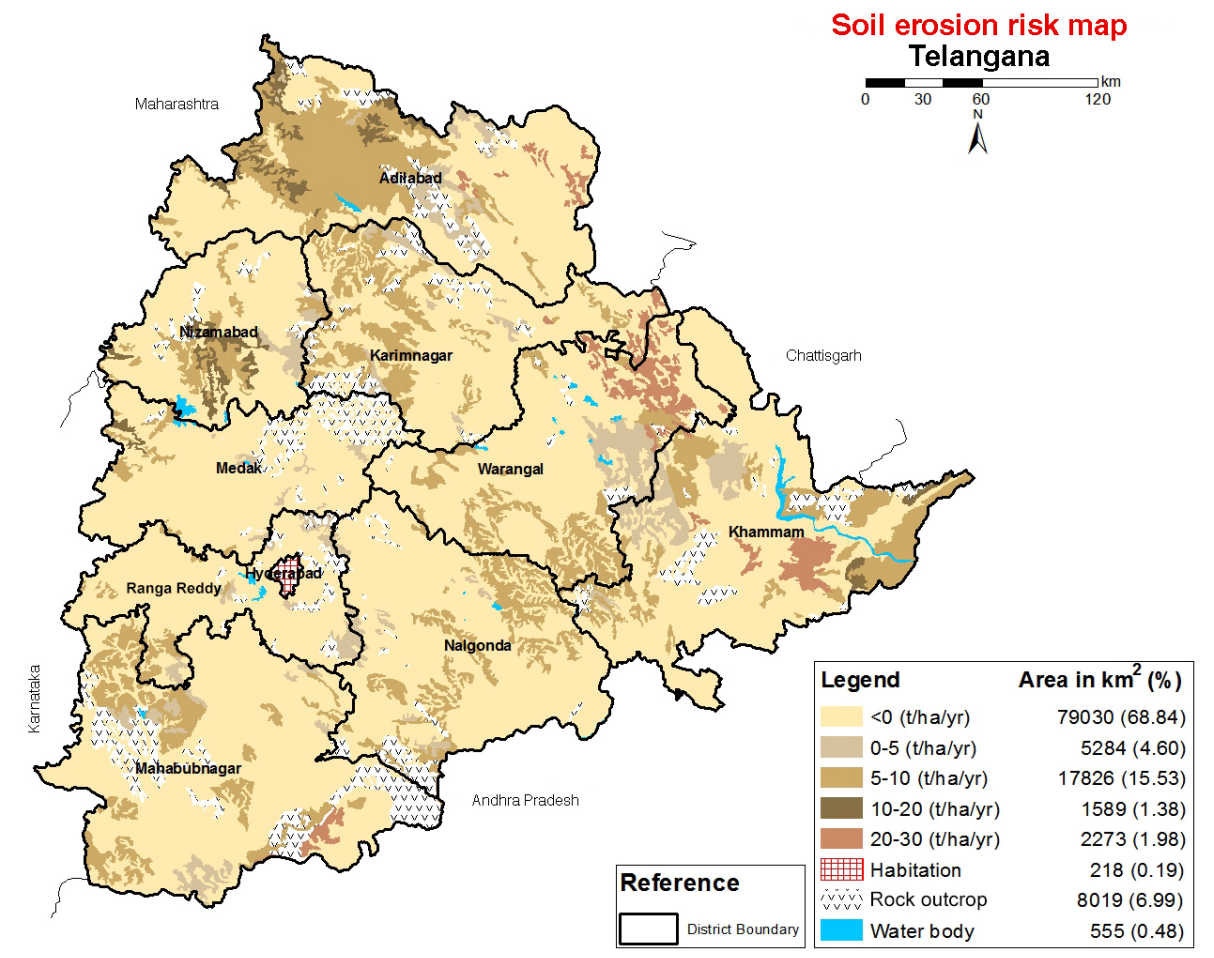

Figure 5. Soil erosion risk map of Telangana.

2006; Mandal and Sharda, 2011). Based on limited experimental data available on the loss of crop productivity visà-vis degree of erosion, it was observed that productivity of maize declined by $5.0 \%$ annually when soil loss exceeded the $T$ value in alluvial soils of humid subtropical regions. Similar results were also reported from the semiarid region of Bellary, Karnataka, where a reduction in yields of sorghum and chickpea was more pronounced as the soil loss exceeded the estimated $T$ value of the region. Analysis of the data generated in these experiments also revealed that the reduction in yields was insignificant at erosion levels below the $T$ value (Mandal and Sharda, 2011).

Permissible soil loss ( $T$ value) and its comparison with the prevailing potential erosion rate would decide the priority for the treatment of a given area. Where the erosion rate far exceeds the $T$ value, intensive conservation measures are needed to bring the $T$ value within permissible limits.

\subsection{Soil erosion risk (SER)}

In areas susceptible to erosion, there is a need for a comprehensive soil conservation plan to prevent catastrophic erosion hazards. Identification and execution of site-specific best management practices is required in these areas and is essential to bring the prevailing erosion rates within the permissible limits which may otherwise adversely affect crop productivity. This could be very useful for deciding restoration practices to control the soil erosion of the high priority areas. Misir et al. (2007) indicated that these problems can be overcome by using predictive models and decision support systems. Land managers and policymakers need to have adequate knowledge of intensity and distribution of soil erosion risk to check land degradation and efficiently plan various cost-effective land-based interventions (Brady and Weil, 2002).

The process of decision-making becomes easier when both the above conditions (erosion and tolerance) are combined into a single parameter, the soil erosion risk (Mandal and Sharda, 2013). An area with a positive value of SER demands measures for soil conservation. The soil erosion risk map generated for Telangana, by deducting the $T$ values from soil erosion rates, is shown in Fig. 5. The results shown in Table 4 revealed that around $69 \%$ of the state has low SER, and does not call for immediate soil conservation measures. The remaining area $(2.17 \mathrm{Mha})$ requires conservation planning albeit through prioritization. Four districts, viz. Adilabad, Warangal, Khammam, and Karimnagar are the most riskprone with more than one-quarter of their total geographical areas showing net positive SER values. Among the four, Adilabad was assigned the highest priority as about $40 \%$ of its area is prone to erosion risk. This could be attributed to (Table 5) the highest (among all districts of Telangana) average annual rainfall $(1157 \mathrm{~mm})$, highest area under shallow soils (36\%), undulating topography (239-543 m above mean sea level), and one of the lowest cropping intensities in the state $(114 \%)$. On the other extreme is Medak, which is the least 
Table 4. Aerial extent (in thousands of hectares) of soil erosion risk classes in different districts of Telangana.

\begin{tabular}{lrrrrr}
\hline \multirow{2}{*}{ District } & \multicolumn{5}{c}{ Soil erosion risk $(R)$ values $\left(\mathrm{Mg} \mathrm{ha}^{-1} \mathrm{yr}^{-1}\right)$} \\
\cline { 2 - 6 } & $<0$ & $0-5$ & $5-10$ & $10-20$ & $20-30$ \\
\hline Adilabad & 876.4 & 81.8 & 459.5 & 74.2 & 27.4 \\
Karimnagar & 773.0 & 46.1 & 244.4 & 0 & 21.8 \\
Khammam & 1068.1 & 111.2 & 272.5 & 19.4 & 63.8 \\
Mahabubnagar & 1293.5 & 63.8 & 245.9 & 0 & 21.0 \\
Medak & 783.6 & 21.6 & 35.3 & 9.0 & 0 \\
Nalgonda & 1077.9 & 35.9 & 210.6 & 0 & 0 \\
Nizamabad & 561.2 & 34.3 & 91.2 & 56.4 & 0 \\
Ranga Reddy & 592.3 & 52.4 & 34.6 & 0 & 0 \\
Warangal & 876.9 & 81.3 & 188.6 & 0 & 93.3 \\
State & $7903.1(68.8)$ & $528.5(4.6)$ & $1782.7(15.5)$ & $158.9(1.4)$ & $227.4(2.0)$ \\
\hline
\end{tabular}

Figures in parentheses are percentages of state areas in a particular $R$ class.

Table 5. Comparison of different districts of Telangana in terms of some statistical parameters.

\begin{tabular}{lrrrrr}
\hline District & $\begin{array}{r}\text { Geographical } \\
\text { area }(\mathrm{M} \mathrm{ha})\end{array}$ & $\begin{array}{r}\text { Net cropped } \\
\text { area (M ha) }\end{array}$ & $\begin{array}{r}\text { Cropping } \\
\text { intensity }(\%)\end{array}$ & $\begin{array}{r}\text { Irrigated } \\
\text { area (\%) }\end{array}$ & $\begin{array}{r}\text { Annual } \\
\text { rainfall (mm) }\end{array}$ \\
\hline Adilabad & 1.61 & 0.58 & 114 & 16.84 & 1157 \\
Karimnagar & 1.17 & 0.55 & 137 & 70.15 & 1521 \\
Khammam & 1.67 & 0.46 & 112 & 41.92 & 1124 \\
Mahabubnagar & 1.84 & 0.86 & 111 & 31.73 & 605 \\
Medak & 0.97 & 0.45 & 135 & 35.42 & 873 \\
Nalgonda & 1.39 & 0.57 & 119 & 42.36 & 674 \\
Nizamabad & 0.80 & 0.33 & 163 & 64.04 & 845 \\
Ranga Reddy & 0.75 & 0.26 & 110 & 32.92 & 781 \\
Warangal & 1.27 & 0.52 & 134 & 65.78 & 955 \\
\hline
\end{tabular}

Source: compiled from various statistical publications of Government of undivided Andhra Pradesh and Government of Telangana.

Table 6. District-wise percentages of the geographical area in different soil erosion risk ranges $\left(\mathrm{Mg} \mathrm{ha}^{-1} \mathrm{yr}^{-1}\right)$ and priority classes.

\begin{tabular}{lrrrrrrl}
\hline District & $0-5$ & $5-10$ & $10-20$ & $20-30$ & $\begin{array}{r}\text { Weighted soil erosion } \\
\text { risk (WSER) }\end{array}$ & $\begin{array}{r}\text { WSER } \\
\text { index }\end{array}$ & $\begin{array}{l}\text { Priority } \\
\text { class (PC) }\end{array}$ \\
\hline Adilabad & 5 & 28 & 5 & 2 & 337.6 & 1.000 & PC-I \\
Warangal & 6 & 15 & 0 & 7 & 309.9 & 0.905 & PC-I \\
Khammam & 7 & 16 & 1 & 4 & 252.4 & 0.707 & PC-I \\
Karimnagar & 4 & 21 & 0 & 2 & 212.3 & 0.569 & PC-II \\
Nizamabad & 4 & 12 & 7 & 0 & 204.8 & 0.543 & PC-II \\
Mahabubnagar & 3 & 13 & 0 & 1 & 137.4 & 0.312 & PC-II \\
Nalgonda & 3 & 15 & 0 & 0 & 120.0 & 0.252 & PC-III \\
Ranga Reddy & 7 & 5 & 0 & 0 & 53.0 & 0.022 & PC-III \\
Medak & 2 & 4 & 1 & 0 & 46.7 & 0.000 & PC-III \\
Weights & 2.5 & 7.5 & 15 & 25 & - & - & - \\
\hline
\end{tabular}

Note: districts with a WER index value of less than $0.290,0.290-0.607$, and more than 0.607 , were grouped in priority classes PC-I, PC-II, and PC-III, respectively. 
erosion-prone district, with only $6 \%$ of its area showing positive SER values. This is probably due to the highest net sown area in the state (46.7\%), higher cropping intensity (135\%), lower rainfall $(873 \mathrm{~mm})$, and relatively flatter general topography (469-620 ma.m.s.1.), leading to a greater area being classified as medium to deep soils (only $8 \%$ of the cultivated soils are shallow, data not shown).

\subsection{Weighted soil erosion risk (WSER)}

The index also categorized the Adilabad district as being of topmost priority as it is the most severely affected district of the state (Table 6). In spite of having the highest share of area $(7 \%)$ in the category $20-30 \mathrm{Mg} \mathrm{ha}^{-1} \mathrm{yr}^{-1}$, Warangal district appears second in the list, owing to the relatively lower area under the risk categories $0-10(15 \%)$ and $10-$ $20 \mathrm{Mg} \mathrm{ha}^{-1} \mathrm{yr}^{-1}(0 \%)$. Medak, with the lowest WER value, is the least affected district of the state.

The WSER index can therefore be considered as an important factor to uncover the threat to agricultural production in a particular district. For example, the top three districts in terms of WSER index viz., Adilabad, Warangal, and Khammam together account for 24, 27, and $32 \%$ of the cereals, pulses, and oilseeds production of Telangana, respectively (DES, Directorate of Economics and Statistics, http://www.aponline.gov.in/apportal/departments/ departments.aspx dep $=09 \&$ org $=72 \&$ category=about). This calls for prioritized soil conservation measures in the districts to ensure minimum loss in crop production. Logically the order of priority in conservation planning would be the areas with a risk exceeding $20(0.23 \mathrm{M} \mathrm{ha})$, followed by 10 (0.16 M ha) and 5 (1.78 M ha) $\mathrm{Mg} \mathrm{ha}^{-1} \mathrm{yr}^{-1}$. However, areas with a high erosion risk may be put to alternate land use as they mostly occur in hilly areas and areas with highly undulating topography, and a huge cost would be involved in applying conservation measures. Therefore, we feel that the highest priority should be accorded to those areas where the risk is between 5 and $10 \mathrm{Mg} \mathrm{ha}^{1} \mathrm{yr}^{-1}$, because if such areas are left untreated for long it may lead to irreversible loss of agricultural land. Among the districts, Adilabad has the highest area (0.46 M ha) with SER 5-10 $\mathrm{Mg} \mathrm{ha}^{-1} \mathrm{yr}^{-1}$, followed by Khammam $(0.27 \mathrm{Mha})$.

\section{Conclusions}

The study has led us to conclude that soil erosion risk values, derived from the presently occurring soil loss under different agro-ecological conditions and the inherent capacity of the soil to tolerate erosion, are a more useful indicator for policymakers and planners to prioritize soil and water conservation activities. The exercise conducted for the youngest state of India allowed us to categorize the districts of the state into different risk classes on the basis of the weighted erosion risk index for management prioritization. Adilabad, Waran- gal, and Khammam are the districts identified to be worst-hit by soil erosion and therefore need immediate attention for natural resource conservation.

Acknowledgements. The authors sincerely thank V. N. Sharda, Ex-Director, CSWCRTI, and Member, ASRB, New Delhi, for his guidance during the implementation of the soil loss tolerance limit project. The authors also thank the anonymous referees for their valuable suggestions for improving this manuscript.

Edited by: P. Pereira

\section{References}

Andrews, S. S., Karlen, D. L., and Mitchell, J. P.: A comparison of soil quality indexing methods for vegetable production systems in northern California, Agric. Ecosys. Environ., 90, 25-45, 2002.

Bhattacharyya, P., Bhatt, V. K., and Mandal, D.: Soil loss tolerance limits for planning of soil conservation measures in Shivalik-Himalayan region of India, Catena, 73, 117-124, doi:10.1016/j.catena.2007.10.001, 2008.

Brady, N. C. and Weil, R. R.: The Nature and Properties of Soils, 74, Prentice Hall, New Jersey, 2002.

Burrough, P. A., MacMillan, R. A., and Deursen, W. V.: Fuzzy classification methods for determining land suitability from soil profile observations and topography, J. Soil Sci., 43, 193-210, 1992.

Chatterjee, S., Krishna, A. P., and Sharma, A. P.: Geospatial assessment of soil erosion vulnerability at watershed level in some sections of the Upper Subarnarekha river basin, Jharkhand, India, Environ. Earth Sci., 71, 357-374, 2014.

Deumlich, D., Kiesel, J., Thiere, J., Reuter, H. I., Volker, L., and Funk, R.: Application of Site Comparison Method (SICOM) to assess the potential soil erosion risk - a basis for the evaluation of spatial equivalence of agri-environmental measures, Catena, 68, 141-152, 2006.

Diamond, J. M.: Collapse: How Societies Choose to Fail or Succeed, Penguin Group Inc., New York, 576 pp., 2005.

FAO: The state of the world's land and water resources for food and agriculture (SOLAW) - Managing systems at risk, Food and Agriculture Organization of the United Nations, Rome and Earthscan, London, 2011.

Fu, B. J., Zhao, W. W., Chen, L. D., Zhang, Q. J., Lu, Y. H., Gulinck, H., and Poesen, J.: Assessment of soil erosion at large watershed scale using RUSLE and GIS: a case study in the Loess Plateau of China, Land Degrad. Dev., 16, 73-85, 2005.

Gajbhiye, K. S. and Mandal, C.: Agro-Ecological Zones, their Soil Resource and Cropping Systems, in: Status of Farm Mechanization in India, edited by: Tyagi, K., Bathla, H., and Sharma S., Indian Agricultural Statistics Research Institute, New Delhi, 132, 2005.

Grossman, R. B., Harms, D. S., Seybold, C. A. and Herrick, J. E.: Coupling use dependent and use-invariant data for soil quality evaluation in the United States, J. Soil Water Cons., 56, 63-68, 2001.

Harris, R. E., Karlen, D. I. and Mulla, D. J.: A conceptual framework for assessment and management of soil quality and health, in: Methods for assessing soil quality, edited by: Doran, J. W. and 
Jones, A. J., Soil Science Society of Amerca Special Publication, No. 49., SSSA Madison, Wisconsin, 1996.

Jha, P., Nitant, H. C., and Mandal, D.: Establishing permissible erosion rates for various landforms in Delhi State, India, Land Degrad. Dev., 20, 92-100, doi:10.1002/ldr.886, 2009.

Karlen, D. L. and Stott, D. E.: A framework for evaluating physical and chemical indicators of soil quality, in: Defining Soil Quality for a Sustainable Environment, edited by: Doran, J. W., Leman, D. C., Bezdicek, D. F., and Stewart, B. A., Soil Science Society of Amerca Special Publication, No. 35., SSSA Madison, Wisconsin, 53-72, 1994.

Kirkby, M. J. and Morgan, R. P. C.: Soil Erosion, John Wiley and Sons, Chichester, West Sussex, UK, 312 pp., 1980.

Kumar, S., Raizada, A., and Biswas, H.: Prioritising development planning in the Indian semi-arid Deccan using sustainable livelihood security index approach, Int. J. Sustain. Dev. World Ecol., 21, 332-345, 2014.

Lakaria, B. L., Biswas, H., and Mandal, D.: Soil loss tolerance values for different physiographic regions of Central India, Soil Use Manage., 24, 192-198, doi:10.1111/j.1475-2743.2008.00155.x, 2008.

Lakaria, B. L., Mandal, D., and Biswas, H.: Permissible soil erosion limits under different landscapes of Chhattisgarh, Indian J. Soil Cons., 38, 148-154, 2010.

Lal, R.: Methods and guidelines for assessing sustainable use of soil and water resources in the tropics, Scientific Publishers, Jodhpur, India, 1996.

Lee, S.: Soil erosion assessment and its verification using the universal soil loss equation and geographic information system: a case study at Boun, Korea, Environ. Geol., 45, 457-465, 2004.

Maji, A.: Assessment of degraded and wastelands of India, J. Indian Soc. Soil Sci., 55, 427-435, 2007.

Maji, A. K., Reddy, G. P. O., and Sarkar, D.: Degraded and wastelands of India: status and spatial distribution, Directorate of Information and Publications of Agriculture, Indian Council of Agricultural Research, New Delhi, 158, 2010.

Mandal, D. and Sharda, V. N.: Assessment of permissible soil loss in India employing a quantitative bio-physical model, Current Sci., 100, 383-390, 2011.

Mandal, D. and Sharda, V. N.: Appraisal of Soil Erosion Risk in the Eastern Himalayan Region of India for Soil Conservation Planning, Land Degrad. Dev., 24, 430-437, doi:10.1002/ldr.1139, 2013

Mandal, D., Dadhwal, K. S., Khola, O. P. S., and Dhayni, B. L.: Adjusted $T$ values for conservation planning in Northwest Himalayas of India, J. Soil Water Cons. 61, 391-397, 2006.

McBratney, A. B. and Odeh, I. O. A.: Application of fuzzy sets in soil science: Fuzzy logic, fuzzy measurements and fuzzy decisions, Geoderma, 77, 85-113, 1997.

Misir, N., Misir, M., Karahalil, U., and Yavuz, H.: Characterization of soil erosion and its implication to forest management, J. Environ. Biol., 28, 185-191, 2007.

NBSSLUP: Soils of India, NBSS Publication No. 94, National Bureau of Soil Survey and Land Use Planning, Nagpur, India, 2002.

Nearing, M. A., Ascough, D. L. and Latlen, J. M: Sensitivity analysis of the WEPP hill slope profile erosion model, Trans. ASAE, 33, 839-849, 1990.

Pimentel, D., Harvey, C., Resosudarmo, P., Sinclair, D., Kurz, D., McNair, M., Crist, S., Shpritz, L., Fitton, L., Saffouri, R., and
Blair, R.: Environmental and economic cost of soil erosion and conservation benefits, Science, 267, 1117-1123, 1995.

Prasannakumar, V., Vijith, H., Abinod, S., and Geetha, N.: Estimation of soil erosion risk within a small mountainous subwatershed in Kerala, India, using Revised Universal Soil Loss Equation (RUSLE) and geo-information technology, Geosci. Front., 3, 209-215, 2012.

Ramamurthy, V., Nalatwadmath, S. K., Srinivas, S., Rama Mohan Rao, M. S., Sivaprasad, C. R., Adhikari, R. N., Naidu, L. G. K., Patil, S. L., Raizada, A., Sarkar, D., Singh, S. K., and Mishra, P. K.: Soil erosion in Karnataka, NBSS Publ. No. 162, NBSSLUP, Nagpur, 70 pp., 2014.

Reddy, R. S., Shiva Prasad, C. R., and Harindranath, C. S.: Soils of Andhra Pradesh for optimizing land use, NBSS Publ. No. 69, Soils of India Series 8, NBSSLUP, Nagpur, 1996.

Reddy, R. S., Nalatwadmath, S. K., and Krishnan, P.: Soil Erosion Andhra Pradesh, NBSS Publ. No. 114, NBSSLUP, Nagpur, 76 pp., 2005.

Reich, P., Eswaran, H., and Beinroth, F.: Global dimensions of vulnerability to wind and water erosion, in: Sustaining the global farm, edited by: Stott, D. E., Mohtar, R. H., and Steinhardt, G. C., Selected papers from the 10th International Soil Conservation Organization Meeting at the Purdue University and the USDAARS National Soil Erosion Research Laboratory, West Lafayette, USA, 24-29 May 1999, 838-846, 2001.

Satyavathi, P. L. A. and Reddy, M. S.: Soil site suitability for six major crops in Telengana region of Andhra Pradesh, J. Indian Soc. Soil Sci., 52, 220-225, 2004.

Scholes, M. C. and Scholes, R. J.: Dust unto dust, Science, 342, 565-566, doi:10.1126/science.1244579, 2013.

Sharda, V. N., Mandal, D., and Ojasvi, P. R.: Identification of soil erosion risk areas for conservation planning in different states of India, J. Environ. Biol., 34, 219-226, 2013.

Singh, K. D.: Participatory watershed management - a key to sustainable agriculture, J. Indian Soc. Soil Sci., 54, 443-451, 2006.

Sotiropoulou, A. M., Alexandridis, T., Bilas, G., Karapetsas, N., Tzellou, A., Silleos, N., and Misopolinos, N.: A user friendly GIS model for the estimation of erosion risk in agricultural land using the USLE, in: Proceedings of the International Conference on Information and Communication Technologies for Sustainable Agri-production and Environment, edited by: Salampasis, M. and Matopoulos, A., Skiathos, Greece, 8-11 September, 2011, 795$801,2011$.

Sys, C.: Land evaluation - Part I, University of Ghent, Ghent, Belgium, 1985.

UNCCD secretariat: A Stronger UNCCD for a Land-Degradation Neutral World, Issue Brief, Bonn, Germany, 2013.

USDA-NRCS.: National soil survey handbook, US Government Printing Office, Washington, DC, 1999.

Volk, M., Moller, M. and Wurbs, D.: A pragmatic approach for soil erosion risk assessment within policy hierarchies, Land Use Pol., 27, 997-1009, 2010.

Wymore, A. W.: Model Based Systems Engineering: An Introduction to the Mathematical Theory of Discrete Systems and to the Tricotyledon Theory of System Design, CRC Press, Boca Raton, Florida, 1993 